NGUYEN van KHANH, Idzi DRZYCIMSKI, Juliusz CHOJNACKI

$\underline{\text { Fish Biology. }}$ $F E E D I N G A N D \mathbb{F O O D} C O M P O S I T I O N$ OF SPRAT $F R O M$
BORNHOLM DEPTH

ODZYWIANIE SIE I PORARM SZPROTA ZREJONU $G \mathbb{E} \mathbb{B} \mathbb{B} O \mathbb{R} N H O L M S I E J$

Institute for Exploitation of Sea Resources

1048 sprat stomachs were subjected to analysis and determination of: qualitative composition of food; average weight of food; percent (quantity) of empty stomachs; index of fulfilment acc. to Blegvad; frequency of plankton appearance in food according to Hertling and nourishment coefficient acc. to Fulton.

\title{
INTRODUCTION
}

Mass catches of sprat during recent years confronted the fish industry with main task directed towards the quality of fish delivered by ship. Sprat pelagic sea fish - feeds entirely on plankton, the composition of which has important influence on technological quality and condition of sprat. The investigations performed up tonow, except of $M$ a n k o w s k i's (1947) and E 1 w e r t o w s ki's (1957b) works had been directed to biology and biologic evaluation of Baltic sprat. The present work contains an accurate feeding analysis of sprat industrially fished in region of Bornholm depth.

\section{MATERIAL AND METHOD}

For investigations, the sprat was obtained from industrial catches carried out between February 1969 and January 1970. The samples were selected at random by about 150 exemples each time and this permitted to examine 1722 pieces. Alimentary ducts of 1048 fishes were guted; filled stomach was weighed after dripping of excess water, thenafter was cut-out and its content was flushed-out with water. After dripping from water, empty stomach was weighed again; obtained difference of weights represented the weight of food. 
Weighing was effected on torsional scale with accuracy to $0.001 \mathrm{~g}$. The food flushed-out from stomach was mixed in measuring vessel of volume $100 \mathrm{~cm}^{3}$ and flooded with water. After thorough mixing, 3 samples each of $1 \mathrm{~cm}^{3}$ were taken and qualitative and quantitative composition of food was determined.

According to obtained measurements additional calculations were made in relation to: percent of empty stomachs, fulfilment index of alimentary ducts according to Bleqvad $W=\frac{\mathrm{g}}{\mathrm{G}} \cdot 1000, \mathrm{~g}$ - weight of food, $\mathrm{G}$ - weight of fish; frequency of food organizms appearance according to Hertling $\left(C=\frac{d}{D} \cdot 100\right.$; number of stomachs for given species, D - number of examined stomachs) and nourishment coefficient according to Fulton $\left(Q=\frac{G}{1^{3}} \cdot 100 ; G\right.$ - total weight of fish, 1 - length of fish body).

\section{RESULTS}

Food of sprat was composed of crustacean plankton belonging to Copepoda and Cladocera; by species their composition during year is not even. The components appearing permanently in food are: Temora longicornis, Cen-. tropages hamatus, Podon sp. and young examples of Copepoda, Seasonally, with frequent domination, appeared: Bosmina coregoni maritima, Pseudocalanus elongatus, Evadne nordmani, E. spinifera, Acartia longiremis, Eu-. rytemora hirundoides and Limnocalanus grimaldii. Structure of food for complete year is illustrated on Fig.1. Basic component of sprat food from Bornholm region are copepods belonging to Calanoida.

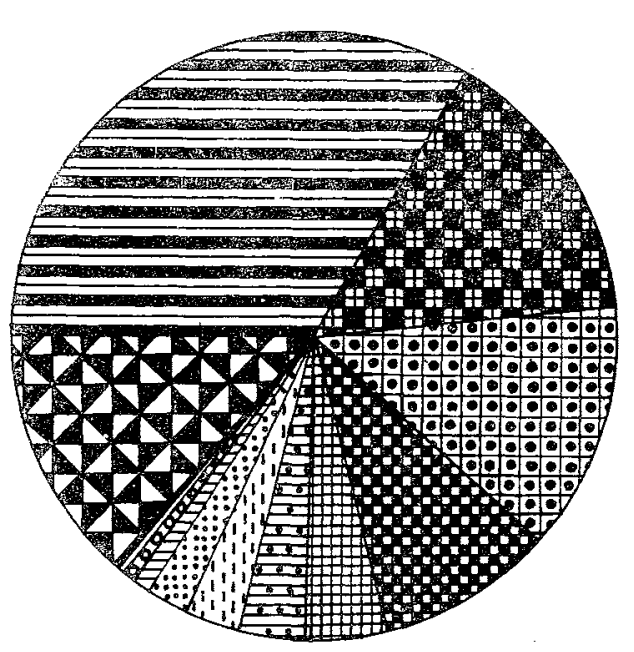

\begin{tabular}{|c|c|}
\hline 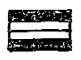 & Temord tongicornis \\
\hline 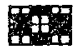 & Copepoda_Calan. (Juven) \\
\hline 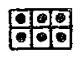 & Bosmina coregoni mariłima \\
\hline & Pseudocalanus elongaius \\
\hline & Podon \\
\hline 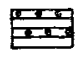 & Centropages hamatus \\
\hline $\begin{array}{ll}0 \\
0 \\
1 & 1 \\
1 & 1 \\
\end{array}$ & Evadne nordmanni \\
\hline & Acartia longiremis \\
\hline & Evadne spinifera \\
\hline 00 & Eurytemora hirundoides \\
\hline & Limnocalanus grimaldii \\
\hline & Copepoda_Calan. (Naupl.) \\
\hline & Copepoda_Calan. ( indef \\
\hline
\end{tabular}

Fig.1. Food composition of sprat in $\%$ by number 
Table 1

Data on the feeding intensity of the Bornholm sprat

\begin{tabular}{|c|c|c|c|c|c|c|c|c|c|c|c|}
\hline \multirow{2}{*}{ Year and month } & \multicolumn{10}{|c|}{1969} & 1970 \\
\hline & II & IV & $\mathrm{V}$ & VI & VII & VIII & IX & $\mathrm{X}$ & $\mathrm{XI}$ & XII & I \\
\hline $\begin{array}{l}\text { Percentage of empty } \\
\text { stomachs }\end{array}$ & 98.0 & 87.0 & 1.0 & 0 & 77.0 & 17.0 & 3.7 & 1.0 & 98.8 & 99.0 & 99.0 \\
\hline $\begin{array}{l}\text { Index of alimentary } \\
\text { canals fulfillment }\end{array}$ & 0 & 2.55 & 86.39 & 162.49 & 44.87 & 34.20 & 80.73 & 53.18 & 0 & 0 & 0 \\
\hline $\begin{array}{l}\text { Coefficient of the } \\
\text { feeding intensity }\end{array}$ & 0 & 0.33 & 85.53 & 162.49 & 10.32 & 28.39 & 77.74 & 52.65 & 0 & 0 & 0 \\
\hline
\end{tabular}


Food composition of sprat in each month ( $\mathrm{n}$ : mean number of food organisms per one alimentary canal) 1970

\begin{tabular}{|c|c|c|c|c|c|c|c|c|c|c|c|c|c|c|c|c|c|c|c|c|c|c|}
\hline \multirow{3}{*}{ Food composition } & \multicolumn{20}{|c|}{1969} & \multicolumn{2}{|c|}{1970} \\
\hline & \multicolumn{2}{|c|}{ II } & \multicolumn{2}{|c|}{ IV } & \multicolumn{2}{|c|}{$\mathrm{v}$} & \multicolumn{2}{|c|}{ VI } & \multicolumn{2}{|c|}{ VII } & \multicolumn{2}{|c|}{ vIII } & \multicolumn{2}{|c|}{ IX } & \multicolumn{2}{|c|}{$\mathrm{x}$} & \multicolumn{2}{|c|}{$\mathrm{XI}$} & \multicolumn{2}{|c|}{ XII } & \multicolumn{2}{|c|}{ I } \\
\hline & $n$ & $\%$ & $\mathrm{n}$ & $\%$ & $\mathrm{n}$ & $\%$ & $n$ & $\%$ & $\mathrm{n}$ & $\%$ & $\mathrm{n}$ & $\%$ & $n$ & $\%$ & $\pi$ & $\%$ & $\mathrm{n}$ & $\%$ & n & $\%$ & $\mathrm{n}$ & $\%$ \\
\hline Copepoda-Calanoidae (naupli) & & & & & 1.1 & 0.1 & & & & & & & & & & & & & & & & \\
\hline Copepoda-Calanoidae (juven) & & & 0.8 & 0.7 & 25.3 & 2.5 & 1599.4 & 36.7 & 225.2 & 23.1 & 3.3 & 0.2 & & & 64.6 & 4.1 & & & & & & \\
\hline Copepoda-Calanoidae (adult): & & & & & & & & & & & & & & & & & & & & & & \\
\hline Acartia longiremis & & & & & 1.0 & 0.1 & 77.6 & 1.8 & 26.3 & 2.7 & 1.2 & 0.1 & & & 158.6 & 10.0 & & & & & & \\
\hline Temora longicornis & & & & & 54.6 & 5.4 & 364.6 & 8.4 & 284.6 & 29.2 & 11.3 & 0.8 & 2148.7 & 73.7 & 913.1 & 57.7 & & & & & & \\
\hline Eurytemora hirundoides & & & & & 0.4 & 0.03 & 5.2 & 0.1 & 1.5 & 0.2 & & & & & 17.2 & 1.1 & & & & & & \\
\hline Centropages hamatus & & & & & 1.8 & 0.2 & 77.6 & 1.8 & 29.1 & 3.0 & 15.6 & 1.1 & 18.2 & 0.6 & 246.5 & 15.6 & & & & & & \\
\hline Pseudocalanus elongatus & & & 45.2 & 42.7 & 600.8 & 59.3 & 504.2 & 11.6 & 23.9 & 2.5 & & & & & & & & & & & & \\
\hline Limnocalanus grimaldii & & & & & 0.9 & 0.1 & 8.1 & 0.2 & & & & & & & 2.0 & 0,1 & & & & & & \\
\hline Copepoda-Calan. (indef) & & & 59.9 & 56.6 & 328.2 & 32.4 & 874.0 & 20.0 & 367.0 & 37.7 & 4.0 & 0.3 & 15.9 & 0.5 & 140.4 & 8.9 & & & & & & \\
\hline Cladocera: . & & & & & & & & & & & & & & & & & & & & & & \\
\hline Evadne nordmanni & & & & & & & 352.9 & 8.1 & 11.1 & 1.1 & & & & & & & & & & & & \\
\hline Evadne spinifera & & & & & & & 51.9 & 1.2 & & & & & & & & & & & & & & \\
\hline Podon sp. & & & & & & & 424.4 & 9.7 & 3.5 & 0.4 & 31.0 & 2.3 & 48.1 & 1.7 & 4.0 & 0.3 & & & & & & \\
\hline Bosmina coregoni maritima & & & & $\overline{100.0}$ & & 100.1 & 23.7 & $\frac{0.5}{100.1}$ & 1.1 & $\frac{0.1}{100.0}$ & 1297.0 & $\frac{95.1}{99.9}$ & 683.1 & $\frac{23.4}{99.9}$ & 37.4 & $\frac{2.4}{100.2}$ & & & & & & \\
\hline $\begin{array}{l}\text { Number of alimentary canals } \\
\text { studied }\end{array}$ & & & 10 & & 10 & & 77 & & & oo & 100 & & 80 & & 10 & 00 & & 82 & & & & \\
\hline $\begin{array}{l}\text { Number of filled alimentary } \\
\text { canals }\end{array}$ & & & 1 & & s & 9 & 77 & & & 23 & 84 & & 77 & & 9 & 99 & & 0 & & 0 & & 0 \\
\hline
\end{tabular}


The analysis of alimentary ducts for 1 year cycle has shown that from November till March, the sprat nearly does not feed at all; this is supported by percent of empty stomachs (98-99\%). In April, This value amounts $87 \%$, but from May, when the spawning begins, number of empty stomachs practically falls down to zero. In July, during intensive spawning, number of empty alimentary ducts increases to $77 \%$ and in October, falls down to 1\%. (Tab.1).

Feeding season of Borpholm sprat begins already in April and lasts till October. Essential changes in qualitative structure of food for particular months take place during this period (Tab.2). Composition and percent participation of species in food is strictly related to their seasonal character. Of certain importance, may also be food selectivity connected probably with accessibility of particular plankton species by sprat during feeding (possibility of escape, part of day, daily migrations of plankton (Fig.2).

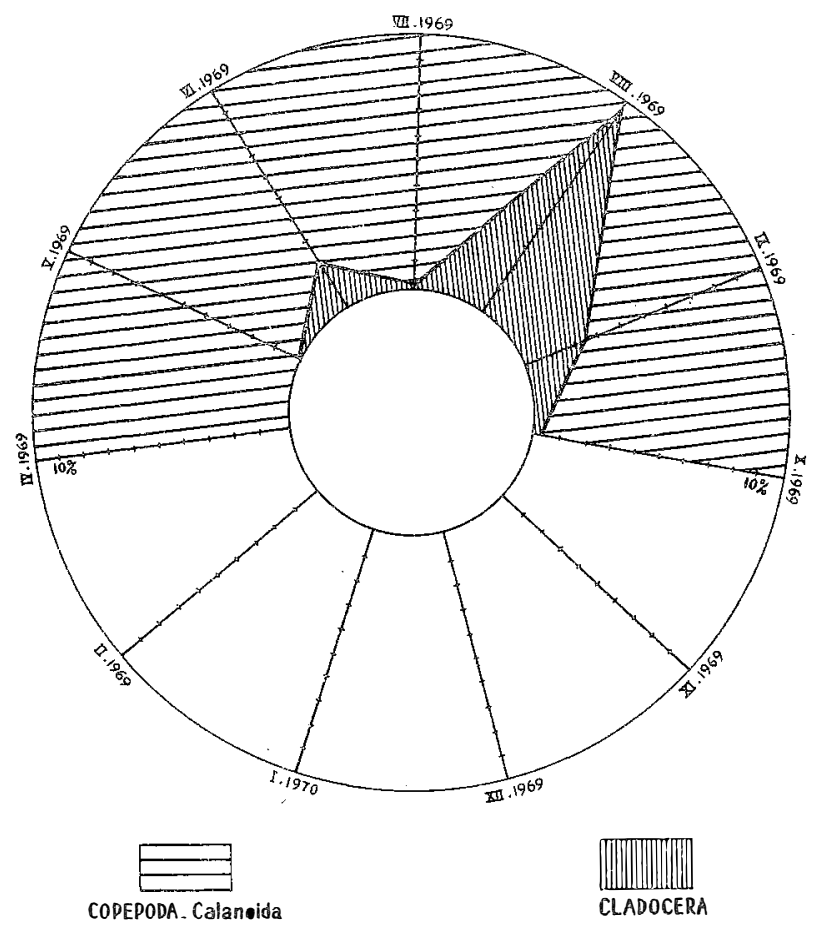

Fig.2. The year cycle participation of Copepoda-Calanoida and Cladocera in the food of sprat expressed in \% by number

Performed analysis permitted to select in food of feeding sprat the species which migrate in masses during certain seasons: Pseudocalanus elongatus (59.3\% in food of May), young stages of Copopoda (36.7\% in June), Bosmina coregoni maritima (95.1\% in August) and Temora longicornis (73.7\% in September). This indicates to changes from basic food with appearance of other species actually appearing in mass within plankton. It may be noted that, Copepoda were appearing continously during whole feeding period regardless 


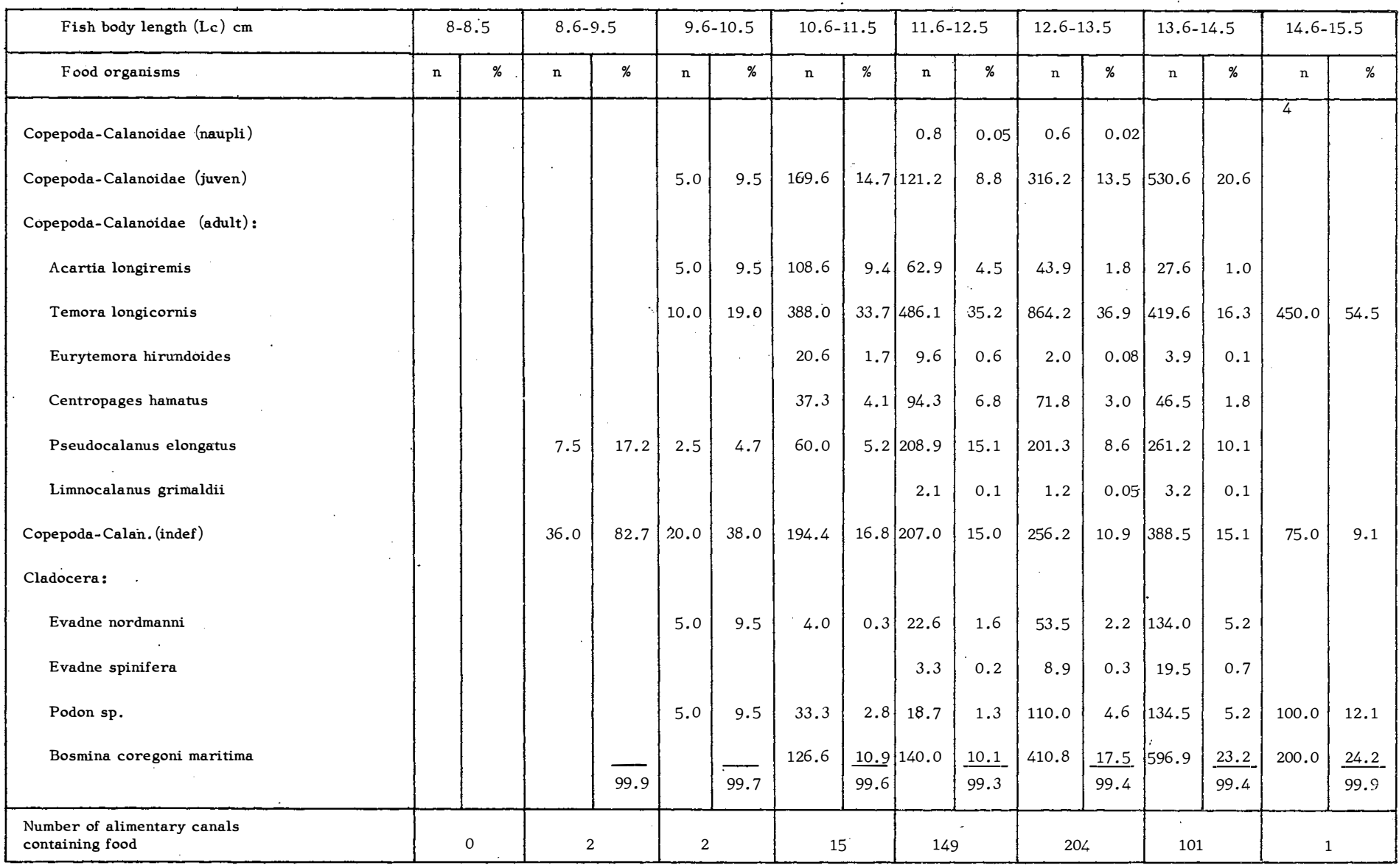


to season, with exception of August, when Cladocera dominate in plankton and food.

Constant and seasonal food of August was compared with specific composition of plankton; ratio of percent value of given species participation in food to percent value in plankton, determined on interest of sprat for given species as food. The ratio above 1 indicates to species preferred by sprat (Fig.2).

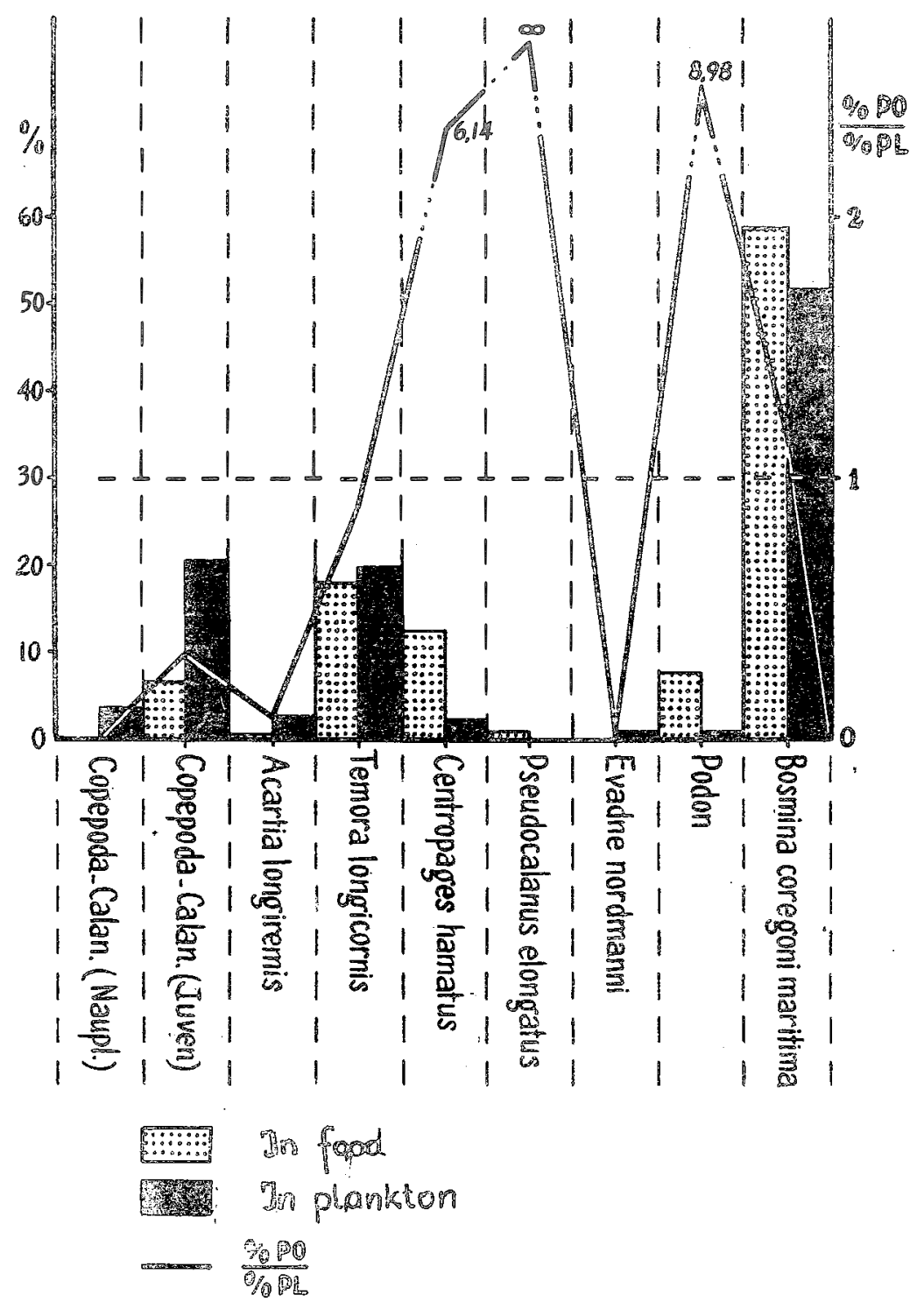

Fig.3. The relationship between species composition of plankton and food composition of sprat in August 1969 


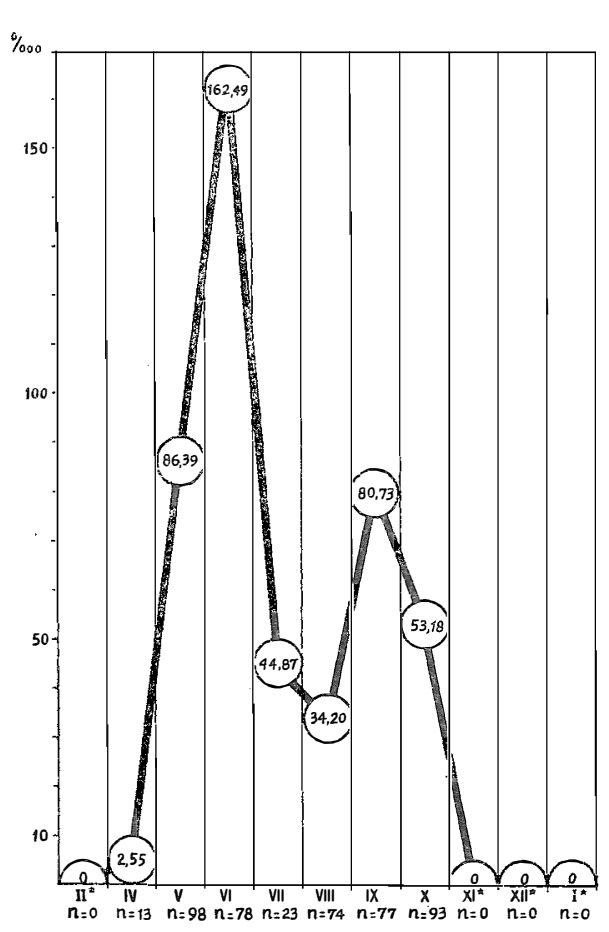

Fig.4. Index of sprat's alimentary duct fulfillment in the year cycle ( $x$ All the specimens examined had empty'stomachs)

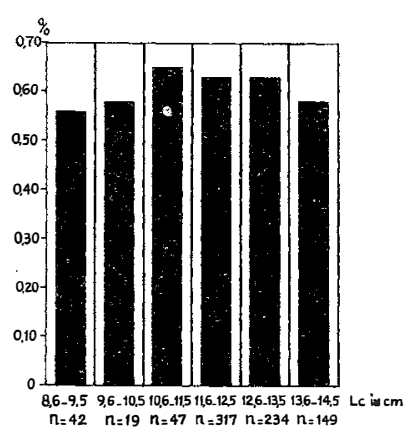

Fig.6. Feeding coefficient - body length re-

lationship of sprat abundance.

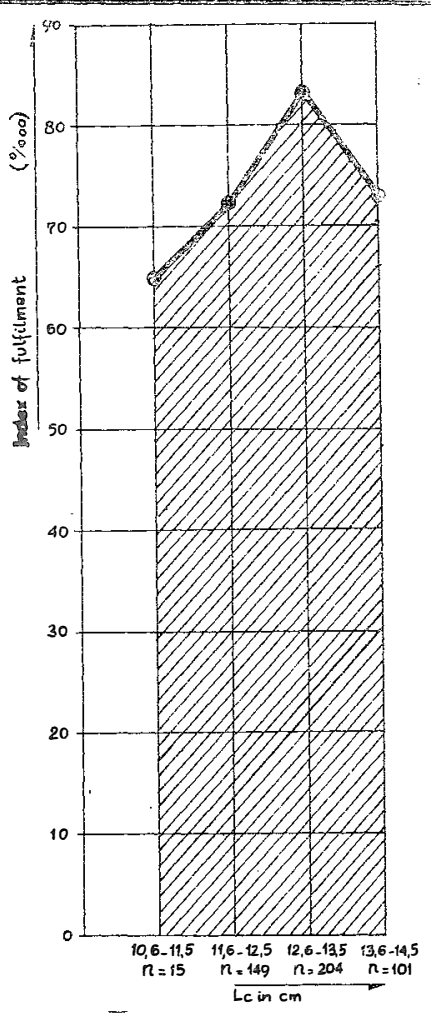

Fig.5. Index of alimentary duct fulfillment in the particular year-classes of sprat An interest of sprat for constant food is large in spite of substantial quality of Bosmina coregoni maritima, which actually was appearing in

The interrelation between food composition of sprat andits length was determined. With its growth in length, the sprat demonstrates higher interest in feeding on Cladocerans and less on Copepods; its interest in feeding on Temora longicornis and Pseudocalanus elongatus remain unchanged as these components are in food constantly. (Tab.3).

The intensiveness of feeding measured by index of fulfilment in alimentary ducts of sprat (Fig.4) or by quantity of food organisms species in stomach of fish (Table 1) indicate large differences in annual cycle. At both measurements two maximum intensiveness of feedingappear: first for June with peak annual value and the second - for September. High value proves also the index of fulfilment of alimentary ducts in May during its growth to spring maximum. 
Index of alimentary ducts fulfilment depends also on size of examined fish (Fig.5). Its value was increasing with size growth of examined fishup to $13.5 \mathrm{~cm}$ at which attained highest value; at larger examples, the value was rapidly decreasing.

Coefficient of feeding or condition of sprat is distinctly changing in annual cycle (Fig.6) and shows certain differences related to fish body. Coefficient of feeding shows low values duringspring. This is post-winter period when fish d• not feed similiarly like during the 'period directly after spawning. All this causes distinct decrease of sprat condition. The condition falls down relatively quickly during winter, even though it is better in February than in August.

The coefficient of nourishment increases during first year of fish life in relation to its growthup to $11.5 \mathrm{~cm}$. At such length, sprat demonstrates best condition (nourishment coefficient $=0.65)$. Further growth of fish causes the decrease of nourishment coefficient and until body length of $13.5 \mathrm{~cm}$, still amounts to 0.63 .

Analysing the intensiveness of feeding meas ured by fulfilment index of alimentary ducts and by nourishment coefficient of sprat (Fig.7), an interrelation between these factors may be

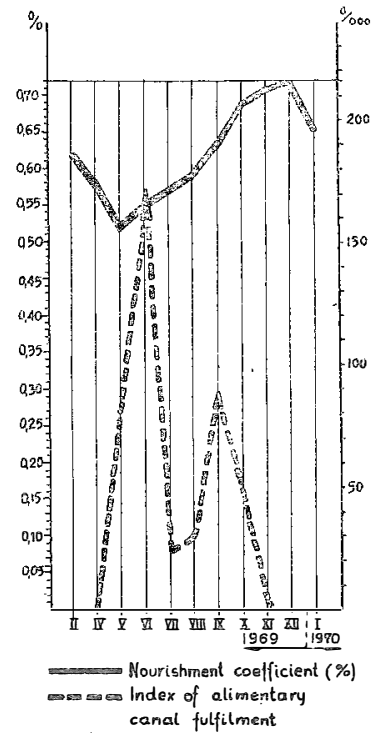

Fig.7. The influence of the feeding intensity on the condition of sprat in the year cycle.

(Body length 13-13.5 cm) noted. Increase or decrease of fulfilment index is preceded by increase or decrease of nourishmentcoefficient. Even, when index of fulfilment indicates distinct variations during feeding season caused among others by spawning, the coefficient of nourishmentindicates at the same time constant increase. Large differences of fulfilment index (decrease during July-August) casue negligent decrease of nourishment coefficient (during August). For whole period of feeding, the coefficient of nourishment increases by about 0.20 . Its initial decreáse after discontinuation of feeding during late autumn and beginning of winter do not change yet the industrial value of sprat. Towards end of .winter and in spring, distinct decrease of nourishment coefficient appears and this makes the sprat of little use for comsumption.

The changes of nourishment coefficient which appeared during the year, show that the following periods characteristic for Bornholm sprat condition may be distinguished:

- period of poor condition: April-August,

- period of medium condition: January-February and September,

- period of good condition: October-December.

It may also be noted that industrial value of sprat during last period is increased owing to fact that alimentary ducts during that time are empty and this increases the value of fish as of material for processing. 


\section{DISCUSSION}

Distinguished components, in sprat food are constant and seasonal.Constant components, which showed quantitative changes, during feed period were presented in examined sprat by Temora longicornis, Centropages hamatus, Podon sp. and young examples of Copepoda not defined yet to species. The first component and to less extent the last one played more important part in food. Remaining two components, even when they were appearing nearly in all feeding periods, were noted in small quantities. E l w e r to w s k i (1957a) accounts also Acartia bifilosa, to constant components of sprat food but he does not mention on Centropages hamatus.

The intensiveness is widely changing during feeding period. For index of feeding intensiveness can be taken the percent of empty alimentary ducts and the coefficient of fulfilment. They do not, however, give the picture of general intensiveness of feeding. To present general intensiveness of feeding, its coefficient was calculated, which resulted from multiplication of quantitative percent of filled alimentary ducts by index of fulfilment and by division of the results by 100 (Tab.1). According to coefficient. obtained from such calculation, it is apparent that its value in April is near zero, while in June is 162.49. For Bornholm sprat of 1969 catches, the feeding period lasted practically 6 months from May to October and its intensiveness during this time varied widely.

These changes may be assigned to several factors, out of which the more important are: temperature of water, spawning, and fish condition. Very low intensiveness of feeding noted in April results from low temperature of water and to relatively poor quantity of planktonin water. In May, the quantity of food increases and the intensiveness of feeding is also increasing. Peak of spring-time development (growth) of zooplankton prevails for June and results in abundancy of food; temperature of water also shows an increase. During this month, the intensiveness of feeding is noted to be highest.

The discussed period including July is distinct for sprat spawning. The spawning process itself is not influencing the intensiveness of feeding. This is evident from May, when in spite of iritensive spawning (Fig.3), very intensive feeding was also noted.For many specimens the post-spawning period prevails for July; some other specimens terminate the spawning in August. Decrease in feeding intensiveness is related to such periods. This period is characteristic for mass growth of Cladocera, which is the main component of food, but the decrease in feeding intensiveness is distinct. Termination of feeding in November probably. results from good condition of sprat and not by decrease of water temperature $\left(\mathrm{ab}, 8^{\circ} \mathrm{C}\right)$. While in spring-time the feeding was most intensive at such temperature, in autumn the intensiveness ceased.

As may appear from the interrelations, above given the mechanism which influences the intensiveness of sprat feeding, is very complex. The obtained results contradict the observations of such authors as $\mathrm{M}$ a n k o ws ki (1947), W r z e s i ń s ki (1969) and of others, who considered that during spawning the sprat limits the feeding or is nearly not feeding at all. It is apparant that this takes place after spawning and not during the spawning. The period of highest intensiveness of sprat feeding in 1970 which pre- 
vailed for May and July, is different in relation to fish from Gdańsk Bay (M a ńk ow s k i, 1947) and for Baltic sprat generally (E l w e r t ows k i, 1957). Basing on the materials of 1970, sprat feeding period may be divided into two subperiods:

- period of intensive feeding (April-July), with peak in June:

- moderate feeding (August-October), with peak in September.

The changes of nourishment coefficient and of fulfilment index or of feeding coefficient demonstrate high interdependence. Increase of feeding coeffi. cient procedes the incre'sse of feeding value. However, the short-lasting changes of feeding coefficient during summer have no essential influence on increase of nourishment coefficient.

\section{REFERENCES}

A n o n y mu s, 1961: Rukovodstvo po izuceniju pitanija ryb w estestvennych usłovijach. - Izdat.Akad. Nauk SSSR. Moskwa.

B l e q v a d, K., 1916: On the food of sprat in the Danish waters within the Skaw. - Rep. Danish Biol.Sta. XXIV.

B l e q v a d, K., 1930: Quantitative investigations of bottom invertebrates in the Kattegat with special reference to the place-food. - Rep. Danish Biol.Sta.XXXVI.

E l w e r t o w s ki, J., 1957a: Polish investigations on the sprat. - Ann. Biol. 12 (1955) Copenhague.

E 1 w e r t ow s ki, J., 1957b: Szprot - biologia, połowy, przetwórstwo. [Sprat - biology, catches, processing]. Gdynia.

F u l t o n, T., 1902: Rate of growth of sea fishes. - Fish.Scotl. Invest. Rept. 20.

H e rting, H., 1928: Untersuchungen uber Ernahrung von Meeresfischen. I. Quantitative Nahrungsuntersuchungen an Pleuronectiden und einigen anderen Fischèn der Ostsee. - Ber. Deutsch.Wiss. Komm. Meeresunters. N.F. IV.2.

M a ń k o w s k j̇, W., 1947: Odżywianie sięi pokarm szprota (Clupea sprattus) Bałtyku Srodkowego. [Food and feeding of Middle-Baltic sprat (Clupea.sprattus)]. - Arch.Hydrob. Ryb.13.

W r z e s ińs ki, O., 1969: Biologiczna ocena stada szprota w Basenach Gdańskim i Gotlandzkim w latach 1967-1968. [Biological evaluation of sprat community in Gdańsk and Gotland aquens during 1967-1968]. - Studia i materiały MIR, Gdynia. 19B. 


\title{
ODZYWIANIE SIE I POKARM SZPROTA Z REJONU GIĘBI BORNHOLMSKIEJ
}

\author{
Streszczenie
}

Przedmiotem analizy była zawartość żołądków szprota z rejonu Głębi Bornholmskiej, która pod względem gatunkowym jest uboższa od pokarmu szprota z innych rejonów Bałtyku. Zerowanie szprota trwa od kwietnia do października, o czym świadczy napełnnienie żołądków szprota. W pokarmie szprota można wydzielić składniki pokarmowe stałe i sezonowe. Współczynnik odíywiania wykazuje wzrost w drugiej polowie roku, a spadek w pierwszej; najniższa jego wartość notowana jest zawsze bezpośrednio przed i po tarle. Szprot o większych rozmiarach wykazuje wybiorczość pokarmową preferując Temora Iongicornis, Pseudocalanus elengatus i wioślarki. Najlepszą kondycję i wartość technologiczna ma szorot o długości do $13,5 \mathrm{~cm}$.

ПИТАНИЕ И КОРМ ШПРОГА ИЗ РАЙОНА БОРНХОЛЬМСКОЙ ВПАДИНЫ

P 0 - 3 10 M

преднетом исследования было содержание желуднов ипрота пз района Борн хольмской ппадины, которое в видовом бтношении ғпляетсл менее разнооразным, чем у шпрота пв других районов Балтики. Нагул ппрота прополжается с апреля по ожтқбр. об әтои свидетельствует наполнение желуднов ппрота. 8 ғорме шпрота щожно выделить тостоянные и сезонные компоненты. богф̆фипиент пптания прота характеризутся увеличением во второй половине года, думеншением лервой: самое низое его значение отмечается всегда непооредственно перед илоде нереста. Шпрот больии размеров проявляет кормовуг прихоливость, предпочитая Teпora longicornis, Pseudocalanus elongatus iл веслоногих рачков. Наплучшую кондицию й технологическую ценность имеет шпрот длиной до $13,5 \mathrm{~cm}$ 。

Received 24.VII.1972

Address:

Doc.dr Idzi Drzycimski

Mgr Juliusz Chojnacki

Instytut Eksploatacji Zasobów Morza A R

Szczecin, ul. Królewicza Kazimierza 4

Polska-Poland 